\title{
Rapid Evaluation of Pathogenicity in Pseudomonas syringae pv. syringae with a Lilac Tissue Culture Bioassay and Syringomycin DNA Probes
}

\author{
Heather J. Scheck, Graduate Student, Marilyn L. Canfield, Senior Faculty Research Assistant, Jay W. Pscheidt, \\ Associate Professor, and Larry W. Moore, Professor, Department of Botany and Plant Pathology, Oregon State \\ University, Corvallis 97331-2902
}

\begin{abstract}
Scheck, H. J., Canfield, M. L., Pscheidt, J. W., and Moore, L. W. 1997. Rapid evaluation of pathogenicity in Pseudomonas syringae pv. syringae with a lilac tissue culture bioassay and syringomycin DNA probes. Plant Dis. 81:905-910.

Losses from diseases caused by Pseudomonas syringae pv. syringae occur on a large number of deciduous woody plants in commercial nurseries in the Pacific Northwest. Bioassays for pathogenicity are one step in the identification of $P$. syringae pv. syringae and are usually performed on the host of isolation; however, woody plants can take months to develop symptoms. A bioassay with highly susceptible lilac (Syringa vulgaris 'Sensation') tissue culture plantlets evaluated pathogenicity in strains of $P$. syringae pv. syringae isolated from 25 species of deciduous woody plants. DNA colony hybridization with the $s y r B$ probe for a syringomycin synthetase gene and the $\operatorname{syr} D$ probe for a syringomycin export gene was also evaluated as a method for identifying pathogens. Of 552 strains provisionally identified as $P$. syringae pv. syringae, $59 \%$ were pathogenic in the bioassay and hybridized with the syr probes, while $19 \%$ were non-pathogenic and did not hybridize with the syr probes, giving $78 \%$ agreement between the two methods. Nine percent of strains were pathogenic in the bioassay but did not hybridize with the syr probes, and $13 \%$ were not pathogenic in the bioassay but did hybridize with the syr probes. These methods detected pathogenic strains of $P$. syringae pv. syringae isolated from diverse woody plants in 5 to 16 days.
\end{abstract}

Pseudomonas syringae pv. syringae infects a wide range of deciduous woody plants in Pacific Northwest nurseries, causing tip dieback, bud and flower blast, spots and blisters on fruit, stem canker, and leaf blight $(6,35)$. Annual losses in woody plant nurseries in Oregon from $P$. syringae pv. syringae are estimated at $\$ 8$ million (40). Because $P$. syringae pv. syringae survives as an epiphyte on many woody and herbaceous plants (26), its association with diseased tissue cannot be equated to pathogenicity. Tests of the pathogenicity of strains of $P$. syringae pv. syringae, isolated either as epiphytes or from diseased plant tissue on the wide variety of potential hosts grown in commercial woody plant nurseries, would require extensive resources, and symptom development could take months (29). A rapid method to evaluate patho-

Corresponding author: L. W. Moore

E-mail: moorel@bcc.orst.edu

Published as technical paper no. 11081 of the Oregon State University Agricultural Experiment Station.

Use of trade names in this article does not imply endorsement by Oregon State University of the products named or criticism of similar products not mentioned.

Accepted for publication 23 April 1997.

Publication no. D-1997-0602-03R

(C) 1997 The American Phytopathological Society genicity of strains of $P$. syringae pv. syringae is crucial for the timely application of chemical sprays for disease control.

The traditional method of diagnosing diseases incited by $P$. syringae pv. syringae involves isolation of the suspected pathogen in pure culture and characterization by a combination of physiological and biochemical tests. The Levan production, Oxidase activity, Potato soft rot, Arginine dihydrolase activity, and Tobacco hypersensitive response (LOPAT) tests $(24,25)$ are used to discriminate $P$. syringae from other species of fluorescent pseudomonads. The Gelatin liquefaction, Aesculin hydrolysis, Tyrosinase activity, and utilization of Tartrate (GATTa) tests (22) are used to separate pathovar syringae from other pathovars of $P$. syringae. More rapid identification of $P$. syringae pv. syringae has been attempted by measuring the ice nucleation activity (INA) of strains $(1,16,20,26,38)$, by bacteriophage typing $(3,4,16)$, and by serology $(14,30,34)$. Because these methods do not directly assess pathogenicity, Young (49) proposed a protocol of 12 nutritional tests, an assay for syringomycin, and a lilac pathogenicity test to identify $P$. syringae pv. syringae.

There is no standard method for evaluating pathogenicity in $P$. syringae pv. syringae. Inoculations of immature pear and sweet cherry fruit $(10,16,36)$, leaves and twigs of apricot, peach, nectarine, and plum, etiolated pear, apple and peach hypocotyls (10), immature yellow tomato fruit $(5,6)$, bean pods $(23)$, lemon fruit and pea stems (30), lilac petioles (49), red maple stems (28) and pear blossoms $(46,48)$ have all been tested. The results of all these methods were variability in symptom expression and low correlation of results from bioassays with physiological or biochemical tests.

Presumably, strains identified as $P$. $s y$ ringae pv. syringae are pathogenic on lilac (Syringa sp.) or share hosts in common with pathogenic strains isolated from lilac (49). Maintaining lilac plants with sufficient young, susceptible leaves or flowers for pathogenicity testing is problematic Yessad et al. (48) showed in vitro microcuttings of pear (Pyrus communis) were superior to pear seedlings or immature pear fruit for detecting pathogenic strains of $P$. syringae pv. syringae. Because lilac can be maintained in a juvenile state in aseptic tissue culture, it has advantages in a bioassay for testing strains of $P$. syringae pv. syringae for pathogenicity.

Pathogenic strains of $P$. syringae pv. syringae may not be equally virulent on any given host $(6,10,16,48)$. DNA hybridization with labeled probes can be a sensitive and accurate method of identifying phytopathogenic bacteria without involving a host plant. Radio-labeled probes have been made to cryptic DNA sequences and used to identify pathogenic strains of Erwinia amylovora (11), P. syringae pv. tomato (9), Xanthomonas campestris pv. phaseoli (13), and Clavibacter michiganense subsp. michiganense (44). Probes for genes required for phaseolotoxin production in $P$. syringae pv. phaseolicola (39) and coronatine production in $P$. syringae pv. tomato (8) have been highly reliable for identifying pathogens in vitro and in planta.

Syringomycin is a necrotizing phytotoxin with antimicrobial activity produced by most strains of $P$. syringae pv. syringae and not by other pathovars of $P$. syringae (51). SyrB, a syringomycin synthetase gene, and $s y r D$, a syringomycin export gene, have been cloned and used as radiolabeled probes (36). Using probes for syringomycin genes is a more direct route for evaluating the toxigenic potential of strains than the standard bioassay, which measures growth inhibition of the syringomycin-sensitive fungus Geotrichum candidum Link (42). The syr sequences were shown to be highly specific to syringomycin-producing strains of $P$. syrin- 
gae pv. syringae isolated from diverse hosts including lilac, citrus, bean, rose, wheat, sugar beet, stone fruit, and pome fruit (36). The $s y r$ probes had no homology to $P$. viridiflava nor to $P$. syringae pvs. phaseolicola, tabaci, tagetis, tomato, morsprunorum or pisi. Thus, syringomycin genes should be useful for identifying pathogenic $P$. syringae pv. syringae isolated from woody plants.

The first objective of this research was to evaluate lilac (Syringa vulgaris) as a possible universal suspect in pathogenicity tests with strains of $P$. syringae pv. syringae isolated from diverse woody plants. The second objective was to test digoxigenin-labeled $s y r B$ and $s y r D$ DNA probes for syringomycin genes as a method to identify pathogens without a bioassay. Results of these two methods were compared with traditional physiological and nutritional tests for identifying $P$. syringae pv. syringae. A preliminary report has been published (7).

\section{MATERIALS AND METHODS}

Isolation and characterization of strains. Deciduous woody plants with cankers, bud and blossom blights, leaf spots, and shoot diebacks were collected from 44 commercial nurseries and seven landscape plantings in the Willamette Valley, Oregon, March through May of 1992 and 1993. Isolation and purification of these strains has been described (40). Strains were provisionally identified as $P$. syringae pv. syringae based on blue-green fluorescence on King's Medium B (KB) (19) under UV at $350 \mathrm{~nm}$ and a negative test result for Gram's stain (38) and cytochrome oxidase activity (21). Bacteria were preserved at $-80^{\circ} \mathrm{C}$ in sterile LuriaBertani broth (31) amended with $20 \%$ sterile glycerol. Before each assay, strains

Table 1. Plant sources of 552 strains of Pseudomonas syringae pv. syringae and the results of pathogenicity tests with a lilac tissue-culture bioassay and DNA colony hybridizations with probes p91 $(s y r B)$ and $\mathrm{p} 9(s y r D)$ for syringomycin genes

\begin{tabular}{|c|c|c|c|c|c|}
\hline \multirow[b]{2}{*}{ Family, genus, and species ${ }^{a}$} & \multirow[b]{2}{*}{ Common name } & \multicolumn{4}{|c|}{$\begin{array}{l}\text { Pathogenicity tests } \\
\left(\text { No. of strains }{ }^{b}\right)\end{array}$} \\
\hline & & $\begin{array}{l}\text { Bio+ } \\
\mathrm{CH}+\end{array}$ & $\begin{array}{l}\text { Bio- } \\
\text { CH- }\end{array}$ & $\begin{array}{l}\text { Bio+ } \\
\text { CH- }\end{array}$ & $\begin{array}{l}\text { Bio- } \\
\text { CH+ }\end{array}$ \\
\hline \multicolumn{6}{|l|}{ Aceraceae } \\
\hline Acer palmatum Thunb. & Japanese maple & 34 & 45 & 21 & 24 \\
\hline A. platanoides L. & Norway maple & 1 & 4 & 0 & 0 \\
\hline A. rubrum $\mathrm{L}$. & Red maple & 6 & 4 & 4 & 3 \\
\hline A. saccharum Marsh. & Sugar maple & 1 & 0 & 0 & 0 \\
\hline A. truncatum Bunge. & Shantung maple & 3 & 0 & 1 & 1 \\
\hline \multicolumn{6}{|l|}{ Berberidaceae } \\
\hline Berberis aquifolium Pursh. & Oregon grape & 2 & 0 & 0 & 0 \\
\hline \multicolumn{6}{|l|}{ Caprifoliaceae } \\
\hline Viburnum dentatum L. & Arrow-wood & 0 & 4 & 2 & 5 \\
\hline \multicolumn{6}{|l|}{ Celastraceae } \\
\hline \multicolumn{6}{|l|}{ Euonymus alatus (Thunb.) } \\
\hline Siebold & Spindle tree & 3 & 0 & 0 & 0 \\
\hline \multicolumn{6}{|l|}{ Ericaceae } \\
\hline Vaccinium corymbosum L. & Highbush blueberry & 3 & 12 & 1 & 1 \\
\hline \multicolumn{6}{|l|}{ Hamamelidaceae } \\
\hline Liquidambar styraciflua L. & Sweet gum & 1 & 3 & 0 & 1 \\
\hline \multicolumn{6}{|l|}{ Hydrangeaceae } \\
\hline Philadelphus coronarius L. & Mock orange & 7 & 2 & 1 & 1 \\
\hline Magnolia grandiflora L. & Southern magnolia & 2 & 9 & 1 & 2 \\
\hline \multicolumn{6}{|l|}{ Oleaceae } \\
\hline Forsythia viridissima Lind. & Golden bells & 11 & 2 & 2 & 2 \\
\hline Syringa amurensis Rupr. & Amur lilac & 1 & 0 & 0 & 2 \\
\hline S. $x$ chinensis Willd. & Chinese lilac & 9 & 0 & 0 & 3 \\
\hline S. $x$ persica $L$ & Persian lilac & 4 & 1 & 0 & 2 \\
\hline S. vulgaris $\mathrm{L}$. & Common lilac & 216 & 9 & 8 & 17 \\
\hline \multicolumn{6}{|l|}{ Rosaceae } \\
\hline Prunus armeniaca $\mathrm{L}$. & Apricot & 4 & 1 & 2 & 1 \\
\hline$P . \operatorname{avium}(\mathrm{L}.) \mathrm{L}$. & Sweet cherry & 5 & 0 & 0 & 1 \\
\hline \multicolumn{6}{|l|}{ P. laurocerasis L. cv. Otto } \\
\hline Leuken & Cherry laurel & 2 & 1 & 0 & 1 \\
\hline P. serrulata Lindl. & Japanese flowering cherry & 1 & 1 & 2 & 2 \\
\hline Pyrus communis L. & Common pear & 2 & 2 & 0 & 2 \\
\hline P. pyrifolia (Burm f.) Nakai & Asian pear & 5 & 5 & 0 & 0 \\
\hline Sorbus aucuparia L. & Mountain ash & 2 & 0 & 0 & 2 \\
\hline \multicolumn{6}{|l|}{ Tiliaceae } \\
\hline Tilia cordata Mill. & European linden & 0 & 2 & 2 & 0 \\
\hline Totals & & 325 & 107 & 47 & 73 \\
\hline
\end{tabular}

a Latin binomials follow those in Scientific and Common Names of 7000 Vascular Plants in the United States. 1995. L. Brako, A. Rossman, and D. Farr, American Phytopathological Society, St. Paul, MN.

b Pathogenic in lilac bioassay = Bio+, non-pathogenic in lilac bioassay = Bio-, positive in colony hybridizations with syr probes $=\mathrm{CH}+$, negative in colony hybridizations with $s y r$ probes $=\mathrm{CH}-$.

were recovered from frozen storage by streaking onto $\mathrm{KB}$ and incubating for $48 \mathrm{~h}$ at $28^{\circ} \mathrm{C}$.

Fluorescent, oxidase-negative, gramnegative strains were further characterized by two determinative schemes: LOPAT tests $(20,25)$ and GATTa tests (22). All strains were tested three times for LOPAT and GATTa characters.

INA of strains was determined by the method of Vali as modified by Lindow et al. (26). Cells were suspended to a concentration of approximately $1 \times 10^{8} \mathrm{CFU} / \mathrm{ml}$ $\left(\mathrm{OD}_{590}=0.3\right)$ in sterile distilled water (SDW). Ten drops (10 $\mu$ l each) of cell suspension were pipetted onto a paraffincoated sheet of aluminum foil floating on a $70 \%$ ethanol solution maintained at $-5^{\circ} \mathrm{C}$ (Exacal 300 bath, Neslab Instruments Inc., Portsmouth, NH). The number of drops that froze within 10 min was recorded; strains with eight or more frozen drops were considered INA. All strains were tested three times.

Tissue cultured plantlets. S. vulgaris 'Sensation' stock plants were obtained from a commercial tissue culture nursery (Microplant Nurseries, Gervais, OR). Plantlets were aseptically cultured in 200 $\mathrm{ml}$ glass jars with plastic lids on $35 \mathrm{ml}$ of solid lilac tissue culture medium (Murashige and Skoog salts [33] 4.3 g, 6-benzylamino-purine $2 \mathrm{mg}$, thiamine $0.4 \mathrm{mg}$, myo-Inositol $100 \mathrm{mg}$, sucrose $30 \mathrm{~g}$, agar $6.5 \mathrm{~g}$, distilled water 1 liter, $\mathrm{pH} 5.2$, all chemicals from Sigma Chemical Co., St. Louis). Plantlets were grown at $25^{\circ} \mathrm{C}$ with a $16 \mathrm{~h}$ photoperiod under $40 \mathrm{~W}$ fluorescent bulbs in a constant temperature room and sub-cultured every 3 to 4 weeks.

Bioassay for pathogenicity. Bacteria were harvested from KB plates and suspended in SDW to a concentration of approximately $1 \times 10^{4} \mathrm{CFU} / \mathrm{ml}\left(\mathrm{OD}_{590}=0.20\right)$. Plantlets were submerged and gently swirled in the bacterial suspension for 30 sec and returned to their jars. Inoculated plantlets in the jars were exposed to a temperature of $-5^{\circ} \mathrm{C}$ for $10 \mathrm{~min}$ to simulate a frost event, and then incubated at $25^{\circ} \mathrm{C}$ with a $16 \mathrm{~h}$ photoperiod. Symptom development on plantlets was observed after 14 days. Highly virulent $P$. syringae pv. syringae strain PAH5/92, isolated from diseased lilac (40), was used as a positive control; non-pathogenic $P$. syringae $\mathrm{pv}$. syringae strain JL2000, isolated from a corn leaf surface (27), and water-inoculated plantlets were used as negative controls. Each strain was tested on three plantlets. Random stock plantlets were sampled periodically for contaminating bacteria, yeast, or fungi by macerating plantlets in SDW and streaking loopfuls of the resulting aqueous solution onto KB. Plates were incubated at $28^{\circ} \mathrm{C}$ for 7 days.

DNA-DNA colony hybridizations. Syringomycin probes were cloned from $P$. syringae pv. syringae strain B301D isolated from diseased pear (16). Probe p91 
for a syringomycin synthetase gene contains a 1,107-bp SalI internal fragment of the $s y r B$ gene cloned into pUC18 and maintained in Escherichia coli DH5 $\alpha$. Probe $\mathrm{p} 9$ for a syringomycin export gene is a 510-bp EcoRI fragment containing 500bp of the $5^{\prime}$-end of the $s y r D$ gene, plus 10 bp of upstream DNA cloned into pUC19 and maintained in E. coli DH5 $\alpha$ (36). DNA fragments were labeled with digoxigenin-11-dUTP (Genius Kit; Boehringer Mannheim Biochemicals, Indianapolis, IN) as directed by the manufacturer.

The $s y r B$ and $s y r D$ probes were used in DNA colony hybridizations to detect syringomycin synthetase and export genes in strains of $P$. syringae pv. syringae isolated from diseased woody plants. For hybridizations, individual bacterial colonies were grown on $\mathrm{KB}$ for $48 \mathrm{~h}$ at $28^{\circ} \mathrm{C}$. Sterilized, non-charged nylon membranes (Qiagen Inc., Chatsworth, CA) were laid on $250 \mathrm{ml}$ of autoclaved, GY agar (modified from Keane et al. [18]: L-glutamic acid 2 g, yeast extract $1 \mathrm{~g}, \mathrm{KH}_{2} \mathrm{PO}_{4} 0.2 \mathrm{~g}, \mathrm{MgSO}_{4}$ $0.5 \mathrm{~g}, \mathrm{NaCl} 0.2 \mathrm{~g}$, agar $15 \mathrm{~g}$, distilled water 1 liter, $\mathrm{pH}$ 7.0; all chemicals from Sigma Chemical Co.) in 23- by $30-\mathrm{cm}$ Pyrex cake pans. Individual bacterial colonies were aseptically transferred onto the membranes and incubated for $24 \mathrm{~h}$ at $28^{\circ} \mathrm{C}$. Cells were lysed by placing the membranes on Whatman 3-mm filter paper saturated with $10 \%$ sodium dodecyl sulfate (SDS) for $30 \mathrm{~min}$. The released DNA was denatured for 30 min on paper saturated with $0.5 \mathrm{M} \mathrm{NaOH}-$ $1.5 \mathrm{M} \mathrm{NaCl}$ and neutralized for $30 \mathrm{~min}$ on paper saturated with $0.5 \mathrm{M}$ Tris- $\mathrm{HCl}(\mathrm{pH}$ 8.0)-1.5 M NaCl. Membranes were dried for $30 \mathrm{~min}$ at $20^{\circ} \mathrm{C}$, then baked for $1 \mathrm{~h}$ at $80^{\circ} \mathrm{C}$ under vacuum. Cell debris was removed by washing $1 \mathrm{~h}$ at $68^{\circ} \mathrm{C}$ in $50 \mathrm{mM}$ Tris- $\mathrm{HCl}$ (pH 8.0), $1 \mathrm{M} \mathrm{NaCl}, 1 \mathrm{mM}$
EDTA and $0.1 \%$ SDS. Pre-hybridization and hybridization solution consisted of $5 \times$ SSC $(1 \times$ SSC $=0.15 \mathrm{M} \mathrm{NaCl}-0.015 \mathrm{M}$ sodium citrate), $1 \%$ blocking reagent (Boehringer Mannheim Biochemicals), $0.1 \%$ N-lauroyl sarcosine, and $0.2 \%$ SDS. Pre-hybridization was performed for a minimum of $1 \mathrm{~h}$ at $68^{\circ} \mathrm{C}$. Hybridization with $10 \mathrm{ng} / \mathrm{ml}$ of digoxigenin-labeled probe was for a minimum of $12 \mathrm{~h}$ at $68^{\circ} \mathrm{C}$. Post-hybridization washes were two 30 min washes at $20^{\circ} \mathrm{C}$ in $2 \times \mathrm{SSC}-0.1 \%$ SDS and two 60 -min washes at $55^{\circ} \mathrm{C}$ in $0.1 \times$ SSC-0.1\% SDS. Membranes were incubated with Anti-digoxigenin (Fab) conjugated to alkaline phosphatase, and DNADNA hybridization was detected colorimetrically with X-phosphate and NBT (Boehringer Mannheim Biochemicals). Strains that hybridized to the probe were dark purple/brown following colorimetric detection, while the strains that did not hybridize remained unstained. Strain B301D was included as a positive control and W4N77, a non-syringomycin producing $P$. syringae pv. syringae strain isolated as an epiphyte on pear, was included as a negative control (36). All colony hybridizations were repeated.

\section{RESULTS}

Isolation and characterization of strains. Five-hundred fifty-two strains of fluorescent, oxidase negative, gram-negative bacteria isolated from diseased tissues of 25 species of woody plants (Table 1) were tested with standard physiological and biochemical diagnostic methods. In LOPAT tests, $P$. syringae strains were expected to be levan positive, oxidase negative, potato soft-rot negative, arginine dihydrolase negative, and tobacco $\mathrm{HR}$ positive. Of the 552 strains tested, $73 \%$ were positive for levan, none caused potato soft-rot, $81 \%$ were arginine dihydrolase negative, and $79 \%$ were positive for tobacco HR (Table 2). Fifty-three percent of strains matched the LOPAT phenotype for $P$. syringae, while $32 \%$ differed in one test, $10 \%$ differed in two tests and $5 \%$ differed in three tests.

In GATTa tests, $P$. syringae pv. syringae strains should liquefy gelatin and hydrolyze aesculin but have no tyrosinase activity and be unable to utilize tartrate. Of the 552 strains tested, 90\% liquefied gelatin, $75 \%$ hydrolyzed aesculin, 94\% lacked tyrosinase activity, and $89 \%$ were unable to utilize tartrate (Table 2). Fifty-nine percent of strains matched the GATTa phenotype for $P$. syringae pv. syringae, while $30 \%$ differed in one test, $10 \%$ differed in two tests, and $1 \%$ differed in three tests. When the two schemes were combined, $42 \%$ of the 552 strains matched the expected results for $P$. syringae pv. syringae. Fiftynine percent of all strains were INA, and $73 \%$ of the strains that conformed to the LOPAT/GATTa profile for $P$. syringae $p v$. syringae were INA.

Pathogenicity bioassay. Of the 552 strains tested, $67 \%$ caused bacterial blight symptoms in the tissue-cultured lilac bioassay (Table 1). Disease symptoms on the lilac plantlets included water soaked lesions on leaves, vein and petiole necrosis, and tip dieback. Symptoms appeared within as little as 2 days after inoculation, and plantlets were completely necrotic after 14 days. Plantlets inoculated with non-pathogenic strain W4N77 or water only showed no disease symptoms after 14 days and no damage from the 10-min exposure to freezing temperatures. No contaminant microorganisms were recovered from the stock plantlets, and $P$. syringae

Table 2. Physiological and biochemical characterization of fluorescent, gram-negative bacteria recovered from diseased woody plants

\begin{tabular}{|c|c|c|c|c|c|c|c|c|c|c|c|}
\hline \multirow[b]{2}{*}{ Phenotype } & \multicolumn{11}{|c|}{$\%$ Strains $(n=552)$} \\
\hline & Total & $\mathrm{Bio}^{\mathrm{a}}$ & Bio- & $\mathrm{CH}+$ & $\mathrm{CH}-$ & Phenotype & Total & Bio+ & Bio- & $\mathrm{CH}+$ & CH- \\
\hline$\overline{\mathrm{L}+}$ & 73 & 52 & 21 & 55 & 18 & $\mathrm{~L}-$ & 27 & 15 & 12 & 15 & 12 \\
\hline $\mathrm{O}-$ & 100 & 67 & 33 & 72 & 28 & $\mathrm{O}+$ & 0 & 0 & 0 & 0 & 0 \\
\hline $\mathrm{P}-$ & 100 & 67 & 33 & 72 & 28 & $\mathrm{P}+$ & 0 & 0 & 0 & 0 & 0 \\
\hline A- & 81 & 60 & 21 & 61 & 20 & $\mathrm{~A}+$ & 19 & 7 & 12 & 9 & 10 \\
\hline $\mathrm{T}_{(\mathrm{HR})}+$ & 79 & 57 & 22 & 61 & 17 & $\mathrm{~T}_{(\mathrm{HR})^{-}}$ & 21 & 11 & 10 & 10 & 12 \\
\hline $\mathrm{L}+\mathrm{O}-\mathrm{P}-\mathrm{A}-\mathrm{T}_{(\mathrm{HR})}+{ }^{\mathrm{b}}$ & 53 & 42 & 11 & 45 & 8 & & & & & & \\
\hline $\mathrm{G}+$ & 90 & 62 & 28 & 64 & 26 & G- & 10 & 6 & 4 & 6 & 4 \\
\hline $\mathrm{A}_{(\mathrm{e})^{+}}$ & 75 & 53 & 22 & 54 & 21 & $\mathrm{~A}_{(\mathrm{e})^{-}}$ & 25 & 15 & 10 & 16 & 9 \\
\hline $\mathrm{T}-$ & 94 & 65 & 29 & 67 & 27 & $\mathrm{~T}+$ & 6 & 3 & 3 & 3 & 3 \\
\hline $\mathrm{Ta}-$ & 89 & 60 & 29 & 63 & 26 & $\mathrm{Ta}+$ & 11 & 8 & 3 & 7 & 4 \\
\hline $\mathrm{G}+\mathrm{A}_{(\mathrm{e})}+\mathrm{T}-\mathrm{Ta}-^{\mathrm{c}}$ & 59 & 44 & 15 & 45 & 14 & & & & & & \\
\hline $\mathrm{L}+\mathrm{O}-\mathrm{P}-\mathrm{A}-\mathrm{T}_{(\mathrm{HR})}+\&$ & & & & & & & & & & & \\
\hline $\mathrm{G}+\mathrm{A}_{(\mathrm{e})}+\mathrm{T}-\mathrm{Ta}-$ & 42 & 34 & 8 & 37 & 5 & & & & & & \\
\hline \multirow[t]{2}{*}{ INA+ } & 59 & 44 & 15 & 47 & 12 & INA- & 41 & 24 & 17 & 24 & 17 \\
\hline & $\begin{array}{l}\text { Matched } \\
\text { all tests }\end{array}$ & $\begin{array}{l}\text { Differed } \\
\text { in } 1 \text { test }\end{array}$ & $\begin{array}{l}\text { Differed } \\
\text { in } 2 \text { tests }\end{array}$ & $\begin{array}{l}\text { Differed } \\
\text { in } 3 \text { tests }\end{array}$ & & & & & & & \\
\hline LOPAT $_{\text {HR }}$ & 53 & 32 & 10 & 5 & & & & & & & \\
\hline $\mathrm{GA}_{(\mathrm{e})} \mathrm{TTa}$ & 59 & 30 & 10 & 1 & & & & & & & \\
\hline
\end{tabular}

a Bio = lilac bioassay, $\mathrm{CH}=$ colony hybridization with syr probes, $\mathrm{L}=$ levan produced on $5 \% \mathrm{wt} / \mathrm{vol}$ sucrose agar, $\mathrm{O}=$ oxidase activity with Kovac's reagent, $\mathrm{P}=$ potato soft-rot, $\mathrm{A}=$ arginine dihydrolase activity, $\mathrm{T}_{(\mathrm{HR})}=$ tobacco hypersensitive response, $\mathrm{G}=$ gelatin liquefaction, $\mathrm{A}_{(\mathrm{e})}=$ aesculin hydrolysis, $\mathrm{T}$ $=$ tyrosinase activity, $\mathrm{Ta}=$ tartrate utilization, INA $=$ ice nucleation active.

b Expected phenotype for Pseudomonas syringae in $\mathrm{LOPAT}_{(\mathrm{HR})}$ tests: $\mathrm{L}+\mathrm{O}-\mathrm{P}-\mathrm{A}-\mathrm{T}_{(\mathrm{HR})}+$.

c Expected phenotype for Pseudomonas syringae pv. syringae in $\mathrm{GA}_{(\mathrm{e})} \mathrm{TTa}$ tests: $\mathrm{G}+\mathrm{A}_{(\mathrm{e})}+\mathrm{T}-\mathrm{Ta}-$. 
pv. syringae was not able to grow on the lilac tissue-culture medium.

The proportion of strains pathogenic in the lilac bioassay varied according to the host from which they were initially isolated (Table 1). Of the 272 strains isolated from diseased lilacs, $88 \%$ were pathogenic in the bioassay, while only $47 \%$ of the 152 strains isolated from diseased maples were pathogenic. Strains from other woody plants were divided about evenly between pathogens and non-pathogens, with the notable exceptions of highbush blueberry and southern magnolia, which had a high proportion of non-pathogenic strains.

DNA colony hybridizations. Of the 552 strains tested, $72 \%$ hybridized with the $s y r$ gene probes (Table 1). None of the strains hybridized with just one of the syr probes. As in the bioassay, some woody hosts yielded a higher percentage of strains that hybridized to the probes than did others (Table 1). Of the strains isolated from lilacs, $93 \%$ hybridized with the probes while only $48 \%$ of the strains isolated from maples hybridized with the probes. The strains from the remaining plants were divided almost evenly between those that hybridized with the probes and those that did not. Notable exceptions again were highbush blueberry and southern magnolia, which had a high proportion of strains that did not hybridize with the probes.

Comparison of lilac bioassay and colony hybridizations with syr gene probes. Results of the lilac bioassay were in $78 \%$ agreement with results of the colony hybridizations. Fifty-nine percent of the strains were positive and $19 \%$ of the strains were negative by both methods (Fig. 1). Of the remaining $22 \%$ of strains, $9 \%$ were pathogenic in the bioassay but did not hybridize with the syr probes, and $13 \%$ were non-pathogenic in the bioassay but hybridized with the syr probes. A higher percentage of strains that matched the established physiological and nutritional phenotypes for $P$. syringae pv. syringae were pathogenic in the lilac bioassay $(88 \%)$ and hybridized with the probes $(93 \%)$ than did strains with alternate phenotypes. Results were obtained from the

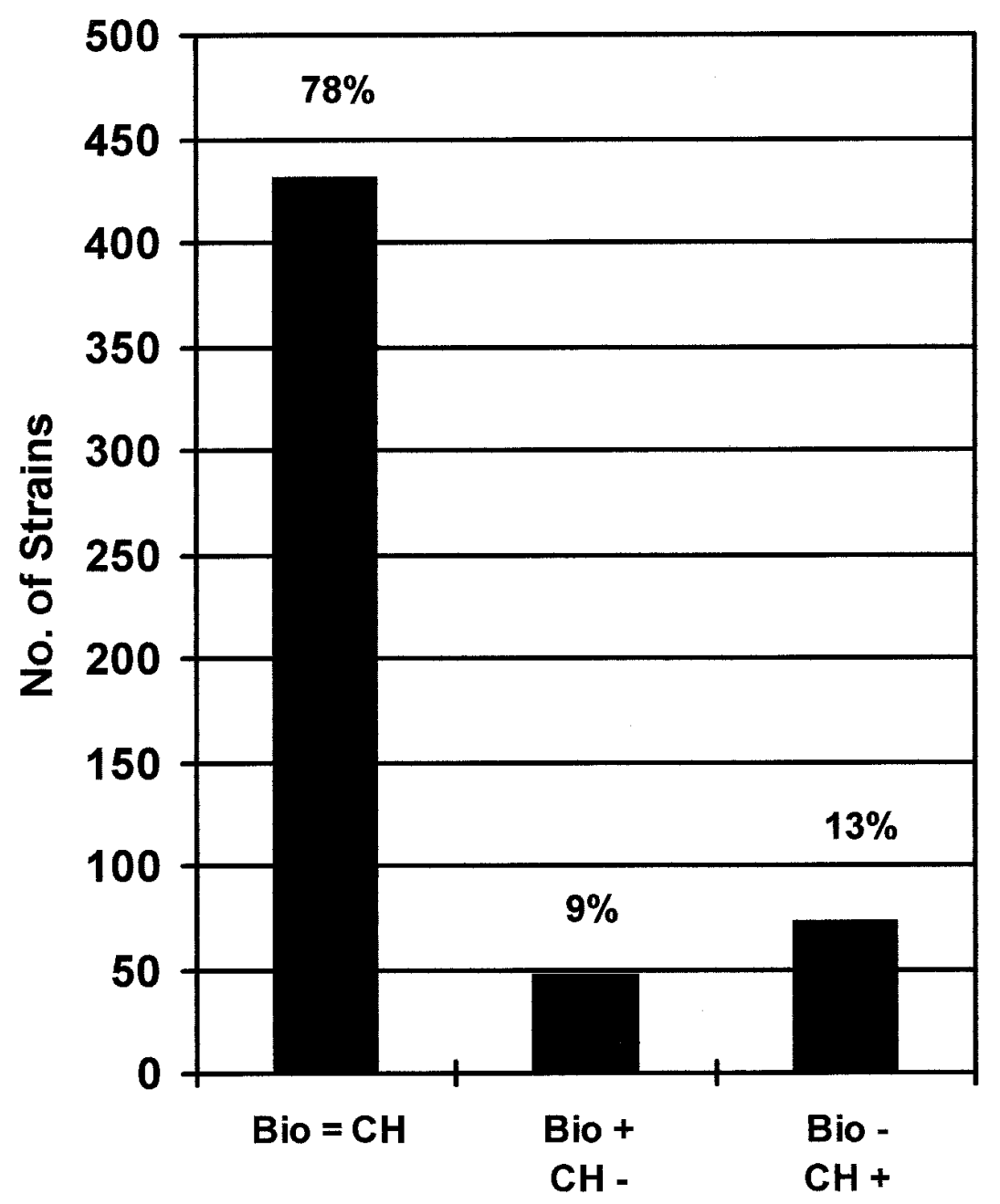

Fig. 1. Comparison of results of pathogenicity testing of 552 Pseudomonas syringae pv. syringae strains from a lilac tissue culture bioassay and DNA colony hybridization with probes $\mathrm{p} 91$ ( $s y r B)$ and p9 $(s y r D)$ for syringomycin genes. Pathogenic in lilac bioassay $=$ Bio+, non-pathogenic in lilac bioassay $=$ Bio-, positive in colony hybridizations with syr probes $=\mathrm{CH}+$, negative in colony hybridizations with syr probes $=\mathrm{CH}-$.

lilac bioassay in 16 days, provided that lilac stock plantlets were available. Colony hybridizations took 5 days.

Predictive value of diagnostic tools. Predictive values describing the likely meaning or correctness of test results were calculated for each of the diagnostic tools used in identifying strains pathogenic on lilac (Table 3). Predictive value of a positive result describes the fraction of positive results which are true positives, while the predictive value of a negative result describes the fraction of negative results which are true negatives (52). All diagnostic tools had a higher positive predictive value than negative predictive value, thus false positives were less frequent than false negatives. The syr probes had the highest predictive values for $P$. syringae pv. syringae pathogenic on lilac ( $82 \%$ positive, $67 \%$ negative). The LOPAT tests were second-highest (79\% positive, $49 \%$ negative), followed by the GATTa tests and INA, which were equal (75\% positive, $44 \%$ negative). The lowest predictive values were from fluorescent, gram-negative, oxidase negative bacteria (67\% positive, $0 \%$ negative).

\section{DISCUSSION}

The lilac tissue culture bioassay and DNA colony hybridization with the $s y r B$ and $s y r D$ probes for syringomycin genes provide two methods for rapid evaluation of pathogenicity in strains of $P$. syringae pv. syringae isolated from woody plants. Lilac plantlets produced uniform disease symptoms and were readily maintained in culture. Because none of the strains hybridized with only one of the probes, both $s y r B$ and $s y r D$ appear to be essential to syringomycin production, and either syr probe could be used exclusively. There was $78 \%$ agreement between the results of the lilac bioassay and hybridization with the syr probes, lending confidence that the two methods give similar results.

The LOPAT and GATTa testing schemes were developed to separate $P$. syringae pv. syringae from other Pseudomonas species and $P$. syringae pathovars, but we found many strains that were pathogenic in the bioassay and hybridized with the syr probes that did not match the predicted results. If used exclusively, the LOPAT and GATTa tests would have underestimated the number of pathogens in our collection of strains by $30 \%$.

These determinative schemes did reveal considerable phenotypic diversity in our collection of presumptive $P$. syringae pv. syringae strains. Seven percent of strains were oxidase negative, arginine dihydrolase active, and pathogenic on lilac. The only phytopathogenic, fluorescent pseudomonad reported to have arginine dihydrolase activity is $P$. marginalis (45); however, $P$. marginalis is oxidase positive (24). Most previous studies have automatically excluded strains with arginine dihydrolase activity as potential pathogens and some 
could have been overlooked. Tobacco hypersensitivity was once believed to be strictly correlated with pathogenicity, but HR-negative pathogens have been identified previously $(1,6,16,22)$. In this study, $11 \%$ of the HR-negative strains were pathogenic on lilac and thus we conclude that this test should not be used exclusively to identify pathogens. None of our strains caused potato soft-rot, so this test was of no benefit in distinguishing between pathogens and non-pathogens.

INA is a common phenotype of pathogenic $P$. syringae pv. syringae $(1,16,26,38)$ and in our study, INA was as well-correlated with pathogenicity as were the GATTa tests. INA could be used as a preliminary screen, but in prior studies it has not been a reliable estimator of pathogenicity in $P$. syringae pv. syringae isolated from woody plants. Only half of the INA $P$. syringae strains isolated by Gross et al. (16) from fruit trees were pathogenic on immature pear and sweet cherry fruit. Fifty-eight percent of the strains isolated by Baca et. al. (1) from woody ornamental plants were INA, yet $69 \%$ were pathogenic on immature tomato fruit.

In previously studies, between 25 and $85 \%$ of the strains provisionally identified as $P$. syringae pv. syringae by physiological and biochemical tests were pathogenic in bioassays $(1,5,6,10,16,22,23,28,30,37$, $38,41,46,49,50)$. In our study, the predictive values (positive or negative) of the LOPAT, GATTa, and INA tests for $P$. $s y$ ringae pv. syringae pathogenic on lilac were between 44 and $79 \%$. When these tests lead to false negative results, concluding that a strain is not pathogenic when it actually is, growers may decide that no chemical disease control measures are needed and experience higher losses. Conversely, if all fluorescent, oxidase-negative, gram-negative bacteria isolated from woody plants are assumed to be pathogenic $P$. syringae pv. syringae, growers may decide to apply chemical bactericides when their use is not warranted.

Our lilac bioassay directly identified pathogens. Using tissue-cultured lilacs eliminates many variables from pathogenicity testing. No competing microflora was detected on or in the lilac plantlets. The microclimate inside the tissue-culture jars was uniform and conducive to disease development. Previous pathogenicity bioassays on lilac required bacteria to be di-

Table 3. Predictive values of diagnostic tools for Pseudomonas syringae pv. syringae pathogenic on tissue-cultured lilacs

\begin{tabular}{lcc}
\hline Diagnostic tool & $\begin{array}{c}\text { Positive predictive value } \\
(\boldsymbol{\%})\end{array}$ & $\begin{array}{c}\text { Negative predictive value } \\
(\boldsymbol{\%})\end{array}$ \\
\hline Gram-negative, oxidase negative & 67 & 0 \\
bacterium, fluorescent of KB $_{\text {LOPAT }_{(\mathrm{HR})}}$ & 79 & 49 \\
$\mathrm{GA}_{(\mathrm{e}) \mathrm{TTa}}$ & 75 & 44 \\
Ice nucleation active $_{\text {Colony hybridization with } \text { syr probes }}^{75}$ & 44 \\
\hline
\end{tabular}

rectly injected into the petioles (49). Briefly subjecting the inoculated plantlets to $-5^{\circ} \mathrm{C}$ mimicked a spring frost event and provided consistent and uniform infection of leaves, petioles and stems.

The percentages of pathogens detected in previous bioassays were especially low when the bioassay host was different than the original host. Although it is common for $P$. syringae pv. syringae strains isolated from diseased tissues to be pathogenic on other hosts, they were usually not as virulent on these other hosts as on their original host $(12,40,43)$. Eighty-eight percent of our strains isolated from lilacs were pathogenic in the bioassay. Of hosts from which at least five strains were tested, more than the average $67 \%$ of strains isolated from mock orange, golden bells, apricot, and sweet cherry were pathogenic on lilac. Fewer than $67 \%$ of the strains isolated from Japanese and Norway maples, highbush blueberry, sweet gum, southern magnolia, common pear, and Asian pear were pathogenic on lilac. The strains that were non-pathogenic on lilac might be epiphytes that are non-pathogens on any host, or else they could have a host range that does not include lilac, making it problematic to classify them as $P$. syringae pv. syringae.

$P$. syringae pv. syringae is the only bacterium known to produce syringomycin, and colony hybridization with the syr genes is a rapid and specific method to identify toxigenic strains. Seventy-two percent of all our strains hybridized with the $s y r B$ and $s y r D$ gene probes for syringomycin. This is fewer than the nearly $90 \%$ of $P$. syringae pv. syringae strains pathogenic on immature cherry fruit that hybridized with the syr probes reported by Quigley and Gross (36). Ninety-three percent of strains isolated from lilac hybridized with the probes, while other plant sources (for example, highbush blueberry and maples) yielded lower percentages of probe-positive strains. The large numbers of non-pathogenic, non-toxigenic strains isolated from diseased tissues that cannot be distinguished from pathogens by standard protocols is one of the confounding factors in diagnosing Pseudomonas-incited diseases of woody plants $(1,6,28,29)$.

Although the probes for syringomycin had the highest predictive values for identifying pathogens of any of the diagnostic tools in this study, 9\% of strains were pathogenic in the bioassay but did not hy- bridize with the syr probes. These strains may produce a different necrotizing toxin, such as syringopeptin (2), or may not rely on toxin production for pathogenesis. One study with peach seedlings reported that $25 \%$ of the canker-causing $P$. syringae pv. syringae strains did not produce syringomycin (34). Mutants rendered defective in syringomycin production were still able to cause small necrotic lesions on immature cherry fruits with an estimated $50 \%$ decrease in virulence $(32,47)$. Thus syringomycin appears to be an important virulence factor, but not an obligate requirement, for pathogenicity in some assays and for some strains. The high proportion of syringomycin-producing strains in natural populations suggests that there is strong selective pressure for toxin production (15).

Thirteen percent of our strains were not pathogenic in the bioassay but hybridized with the probes for syringomycin. Nonpathogenic, syringomycin-producing strains of $P$. syringae pv. syringae have been isolated from maize (17) and from pome and stone fruit trees (16). Quigley and Gross (36) speculated that toxin production in these strains might be an altered phenotype selected through extensive laboratory culture. $S y r B$ and $s y r D$ sequences were found in eight strains of $P$. syringae pv. syringae that were non-pathogenic on immature cherry fruit, most of which produced only low levels of syringomycin when grown on selected media. Strains that produce low levels of syringomycin would be probe-positive, even if they were very weakly pathogenic and unable to parasitize the lilac plantlets in our bioassay.

The majority of our strains, isolated from a wide variety of woody plants, were pathogenic on lilac and hybridized with the probes for syringomycin, allowing for rapid evaluation of pathogenicity in strains provisionally identified as $P$. syringae pv. syringae. Digoxigenin-labeling produced relatively inexpensive, stable, and sensitive syr probes that could be used in diagnostic labs without facilities for handling radioactivity. For routine diagnosis, a large number of suspected pathogens could be tested very rapidly for syringomycin genes by colony hybridization, and a smaller subset of those strains could be tested for pathogenicity on lilac. The syringomycin probes should be tested in squash or dotblot hybridizations for their capacity to identify pathogenic strains of $P$. syringae pv. syringae in plant tissue. If successful, growers could submit plant samples, receive a diagnosis, and commence disease management practices in less than a week.

\section{ACKNOWLEDGMENTS}

This project was supported in part by the Oregon Association of Nurserymen and the Center for Applied Agricultural Research. We thank Dr. D. C. Gross for providing the probes for syringomycin and reviewing the manuscript, Dr. V. O. Stockwell for reviewing the manuscript, and Dr. J. M. Young for helpful comments. 
LITERATURE CITED

1. Baca, S., Canfield, M. L., and Moore, L. W. 1987. Variability in ice-nucleation strains of Pseudomonas syringae isolated from diseased woody plants in Pacific Northwest nurseries. Plant Dis. 71:412-415.

2. Ballio, A., Barra, D., Bossa, F., Collina, A., Grgurina, I., Marino, D., Moneti, G., Paci, M., Pucci, P., Segre, A., and Simmaco, M. 1991. Syringopeptins, new phytotoxic lipodepsipeptides of Pseudomonas syringae pv. syringae. FEBS Lett. 291: 109-112.

3. Billing, E. 1963. The value of phage sensitivity tests for the identification of phytopathogenic Pseudomonas spp. J. Appl. Bacteriol. 26:193-210.

4. Billing, E. 1970. Further studies on the phage sensitivity and the determination of phytopathogenic Pseudomonas spp. J. Appl. Bacteriol. 33:478-491.

5. Cameron, H. R. 1970. Pseudomonas content of cherry trees. Phytopathology 60:13431346.

6. Canfield, M. L., Baca, S., and Moore, L. W. 1986. Isolation of Pseudomonas syringae from 40 cultivars of diseased woody plants with tip dieback in Pacific Northwest nurseries. Plant Dis. 70:647-650.

7. Canfield, M. L., Bateham, L. M., Lu, S-F., Scheck, H. J., and Moore, L. W. 1994. Use of Syringa plantlets in tissue culture and syringomycin DNA probes to rapidly evaluate pathogenicity of Pseudomonas syringae isolates. (Abstr.) Phytopathology 84:1135.

8. Cupples, D. A., Moore, R. A., and Morris, V. L. 1990. Construction and use of a nonradioactive DNA hybridization probe for detection of Pseudomonas syringae pv. tomato on tomato plants. Appl. Environ. Microbiol. 56:1743-1749

9. Denny, T. 1988. Differentiation of Pseudomonas syringae pv. tomato from $P$. syringae pv. syringae with a DNA hybridization probe. Phytopathology 78:1186-1193.

10. Endert, E., and Ritchie, D. F. 1984. Detection of pathogenicity, measurement of virulence, and determination of strain variation in Pseudomonas syringae pv. syringae. Plant Dis. 68:677-680.

11. Falkenstein, H., Bellemann, P., Walter, S., Zeller, W., and Geider, K. 1988. Identification of Erwinia amylovora, the fireblight pathogen, by colony hybridization with DNA from plasmid pEA29. App1. Environ. Microbiol. 54:2798-2802.

12. Garrett, C. M. E., Panagopoulus, C. G., and Crosse, J. E. 1966. Comparison of plant pathogenic pseudomonads from fruit trees. J. Appl. Microbiol. 29:342-356.

13. Gilbertson, R. L., Maxwell, D. P., Hagedorn, D. M., and Leong, S. A. 1989. Development and application of a plasmid DNA probe for detection of bacteria causing common bacterial blight of bean. Phytopathology 79:518525 .

14. Grondeau, C., Saunier, M., Poutier, F., and Samson, R. 1992. Evaluation of physiological and serological profiles of Pseudomonas syringae pv. pisi for pea blight identification. Plant Pathol. 41:495-505.

15. Gross, D. C. 1991. Molecular and genetic analysis of toxin production by pathovars of Pseudomonas syringae. Annu. Rev. Phytopathol. 29:247-278.

16. Gross, D. C., Cody, Y. S., Proebsting, E. L. Jr., Radamaker, G. K., and Spotts, R. A. 1984. Ecotypes and pathogenicity of ice-nucleationactive Pseudomonas syringae isolated from deciduous fruit tree orchards. Phytopathology 74:241-248.
17. Gross, D. C., and De Vay, J. E. 1977. Production and purification of syringomycin, a phytotoxin produced by Pseudomonas syringae. Physiol. Plant Pathol. 11:13-28.

18. Keane, P. J., Kerr, A., and New, P. B. 1970. Crown gall of stone fruit. II. Identification and nomenclature of Agrobacterium isolates. Aust. J. Biol. Sci. 23:585-595.

19. King, E. O., Ward, M. K., and Raney, D. E. 1954. Two simple media for the demonstration of pyocyanin and fluorescein. J. Lab. Clin. Med. 44:301-307.

20. Klement, Z. 1963. Rapid detection of the pathogenicity of phytopathogenic pseudomonads. Nature 199:299-300.

21. Kovacs, N. 1956. Identification of Pseudomonas pyocyanea by the oxidase reaction. Nature 178:703.

22. Latorre, B. A., and Jones, A. L. 1979. Pseudomonas morsprunorum, the cause of bacterial canker of sour cherry in Michigan, and its epiphytic association with $P$. syringae. Phytopathology 69:335-339.

23. Legard, D. C., and Hunter, J. E. 1990. Pathogenicity on bean of Pseudomonas syringae pv. syringae recovered from the phylloplane of weeds and from bean crop residue. Phytopathology 80:938-942.

24. Lelliott, R. A., Billing, E., and Hayward, A. C. 1966. A determinative scheme for the fluorescent plant pathogenic pseudomonads. J. Appl. Bacteriol. 29:470-489.

25. Lelliott, R. A., and Stead, D. E. 1987. Methods in Plant Pathology Vol. 2: Methods for the Diagnosis of Bacterial Diseases of Plants. Blackwell Scientific Publications. Oxford, UK.

26. Lindow, S. E., Arny, C. C., and Upper, C. D. 1978. Distribution of ice nucleation-active bacteria on plants in nature. Appl. Environ. Microbiol. 36:831-838.

27. Loper, J. E., Orser, C. S., Panopoulos, N. J., and Schroth, M. N. 1984. Genetic analysis of fluorescent pigment production in Pseudomonas syringae pv. syringae. J. Gen. Microbiol. 130:1507-1515.

28. Malvick, D. K., and Moore, L. W. 1988. Survival and dispersal of a marked strain of Pseudomonas syringae in a maple nursery. Plant Pathol. 37:573-580.

29. Malvick, D. K., and Moore, L. W. 1988. Population dynamics and diversity of Pseudomonas syringae on maple and pear trees and associated grasses. Phytopathology 78:1366-1370.

30. Mazarei, M., and Kerr, A. 1990. Distinguishing pathovars of Pseudomonas syringae on peas: nutritional, pathogenicity and serological tests. Plant Pathol. 39:278-285.

31. Miller, J. H. 1972. Experiments in Molecular Genetics. Cold Spring Harbor Laboratory, Cold Spring Harbor, NY.

32. Mo, Y.-Y., and Gross, D. C. 1991. Expression in vitro and during plant pathogenesis of the $s y r B$ gene required for syringomycin production by Pseudomonas syringae pv. syringae. MPMI 4:610-620.

33. Murashige, T., and Skoog, F. 1962. A revised medium for rapid growth and bioassays with tobacco tissue cultures. Physiol. Plant. 15:473-497.

34. Otta, J. D., and English, H. 1971. Serology and pathology of Pseudomonas syringae. Phytopathology 61:443-452.

35. Pscheidt, J. W. ed. 1996. Pacific Northwest Plant Disease Control Handbook. Oregon State University Extension Service, Corvallis, OR.

36. Quigley, N. B., and Gross, D. C. 1994. Syringomycin production among strains of $\mathrm{Pseu}$ - domonas syringae pv. syringae: conservation of the $\operatorname{syr} B$ and $\operatorname{syrD}$ genes and activation of phytotoxin production by plant signal molecules. MPMI 7:78-90.

37. Roos, I. M. M., and Hattingh, M. J. 1983. Fluorescent pseudomonads associated with bacterial canker of stone fruit in South Africa. Plant Dis. 67:1267-1269.

38. Schaad, N. W. ed. 1988. Laboratory Guide for Identification of Plant Pathogenic Bacteria. 2nd ed. American Phytopathological Society, St. Paul, MN

39. Schaad, N. W., Peet, R. C., and Panopoulos, N. K. 1989. Identification of Pseudomonas syringae pv. phaseolicola by a DNA hybridization probe. Phytopathology 79:903-907.

40. Scheck, H. J., Pscheidt, J. W., and Moore, L. W. 1996. Copper and streptomycin resistance in strains of Pseudomonas syringae from $\mathrm{Pa}-$ cific Northwest nurseries. Plant Dis. 80:10341039 .

41. Seemuller, E., and Arnold, M. 1978. Pathogenicity, syringomycin production and other characteristics of pseudomonad strains isolated from deciduous fruit trees. Pages 703-710 in: Proc. Int. Conf. Plant Pathog. Bact., 4th.

42. Sinden, S. L., DeVay, J. E., and Backman, P. A. 1971. Properties of syringomycin, a wide spectrum antibiotic and phytotoxin produced by Pseudomonas syringae, and its role in bacterial canker disease of peach trees. Physiol. Plant Pathol. 1:199-214.

43. Smilanick, J. L., Gouin-Behe, C. C., Margosan, D. A., Bull, C. T., and Mackey, B. E. 1996. Virulence on citrus of Pseudomonas syringae strains that control postharvest green mold of citrus fruit. Plant Dis. 80:1123-1128.

44. Thompson, E., Leary, J. V., and Chun, W. W. C. 1989. Specific detection of Clavibacter michiganense subsp. michiganense by a homologous DNA probe. Phytopathology 79:311-314.

45. Thornley, M. J. 1960. The differentiation of Pseudomonas from other Gram-negative bacteria on the basis of arginine metabolism. J. Appl. Bacteriol. 49:557-561.

46. Whitesides, S. K., and Spotts, R. A. 1991. Frequency, distribution, and characteristics of endophytic Pseudomonas syringae in pear trees. Phytopathology 81:453-457.

47. Xu, G.-W., and Gross, D. C. 1988. Evaluation of the role of syringomycin in plant pathogenesis by using Tn5 mutants of Pseudomonas syringae pv. syringae defective in syringomycin production. Appl. Environ Microbiol. 54:1345-1353.

48. Yessad, S., Manceau, C., and Luisetti, J. 1992 A detached leaf assay to evaluate virulence and pathogenicity of strains of Pseudomonas syringae pv. syringae on pear. Plant Dis. 76:370-373.

49. Young, J. M. 1991. Pathogenicity and identification of the lilac pathogen, Pseudomonas syringae pv. syringae van Hall 1902. Ann. Appl. Biol. 118:283-298.

50. Young, J. M., and Triggs, C. M. 1994 Evaluation of determinative tests for pathovars of Pseudomonas syringae van Hall 1902 J. Appl. Bacteriol. 77:195-207.

51. Zhang, L., and Takemoto, J. Y. 1987. Effects of Pseudomonas syringae phytotoxin, syringomycin, on plasma membrane functions of Rhodotorula pilimanae. Phytopathology 77:297-303

52. Zweig, M. H., and Robertson, E. A. 1987 Clinical validation of immunoassays: a welldesigned approach to a clinical study. Pages 97-126. in: Immunoassay, A practical guide. D. W. Chen and M. T. Perlstein, eds. Academic Press, New York. 